\title{
ArcheoSciences
}

Revue d'archéométrie

33 (suppl.) | 2009

Mémoire du sol, espace des hommes

\section{Integrated geophysical and LIDAR surveys at the archaeological site of Ancient Epomanduodurum, Mandeure-Mathay (Franche-Comté, Eastern France)}

Matthieu Thivet, Gilles Bossuet and Clément Laplaige

\section{(2) OpenEdition}

\section{Journals}

Electronic version

URL: https://journals.openedition.org/archeosciences/1486

DOI: 10.4000/archeosciences. 1486

ISBN: 978-2-7535-1599-4

ISSN: $2104-3728$

\section{Publisher}

Presses universitaires de Rennes

\section{Printed version}

Date of publication: 30 October 2009

Number of pages: 151-154

ISBN: 978-2-7535-0943-6

ISSN: $1960-1360$

\section{Electronic reference}

Matthieu Thivet, Gilles Bossuet and Clément Laplaige, "Integrated geophysical and LIDAR surveys at the archaeological site of Ancient Epomanduodurum, Mandeure-Mathay (Franche-Comté, Eastern France)", ArcheoSciences [Online], 33 (suppl.) | 2009, Online since 30 October 2011, connection on 01 February 2022. URL: http://journals.openedition.org/archeosciences/1486 ; DOI: https://doi.org/ 10.4000/archeosciences.1486 


\title{
Integrated geophysical and LIDAR surveys at the archaeological site of Ancient Epomanduodurum, Mandeure-Mathay (Franche-Comté, Eastern France)
}

\author{
Matthieu Thivet*, Gilles Bossuet* and Clément Laplaige*
}

Key words: Integrated geophysical survey, Gallo Roman Town, Automatic Resistivity Profiling, Magnetic mapping, LIDAR.

Integrated geophysical studies were carried out over several years, at Mandeure-Mathay (Franche-Comté Region, Eastern France) for the archaeological evaluation of ancient Epomanduodurum. The site is of major scientific interest to understand the territorial structure of earlier agglomerations in Eastern Gaul at the end of the Iron Age and during the Roman period. As regards its size, urban equipment, monuments and function, the ancient town is considered rating second behind the civitas capital of Sequani, BesançonVesontio. It is located in the Doubs valley, where the plain of Alsace opens into the marches of Burgundy, in a traffic zone between the Vosges and the Jura. This location allows transit between the Rhône valley and the Rhein plain, through the Saône and Doubs valleys. This geographical situation was a significant factor in the creation of the late Iron Age settlement, later to turn into a major Gallo-roman town. The whole site of the Ancient town includes urban centre and two artisan suburbs. The buried ruins stretch on more than 500 hectares outside and inside a meander of the Doubs River.

From the beginning of the survey, in 2001, high resolution and non invasive geophysical methods were performed on large scale, both on the terrace and in the floodplain.
Automatic Resistivity Profiling (ARP) and magnetic mapping covered areas of respectively 60 and 40 hectares $^{1}$ (Fig. 1) Ground penetrating radar was occasionally used to confirm the detection of specific anthropogenic anomalies. Numerous relics of public buildings as varied as temples, castellum, thermae, artisanal and residential quarters, streets or local road system were revealed by geophysical prospecting. These results greatly broaden and enrich the knowledge of the spatial pattern of this site's buried relics. Detailed information about the use and chronology of several monumental structures were obtained by restricted excavations (Fig. 2)

In our new research program (LIEPPEC and PCR Mandeure, 2008-2010), it appears necessary to better understand the connections, both in time and in space, between human occupation and the surrounding region, not only at the Roman period and the late Iron Age, but also during prehistoric, medieval and modern periods. In that way, we have defined a square window of $80 \mathrm{~km}^{2}$, surrounding the Ancient site of Epomanduodurum (Fig. 3)

This study is based on multi-data crossing, including:

- Geophysical prospecting (principally magnetic and electromagnetic)

* UMR 6249, CNRS. Laboratoire de Chrono-environnement, UFR Sciences et Techniques. 25030 Besançon cedex France.

1. Data acquisition and processing in 2001-2008 : S. Lacaze, E. Barrès, L. Aubry, E. Marmet, M. Dabas, J.-M. Vallet, A. Favard, L. Sarro, M. Chemin, G. Hullin, S. Trillaud (Terra Nova) and G. Bossuet, M. Thivet, Y. Bière, A. Mourot, M. Chassang (PCR Mandeure) 


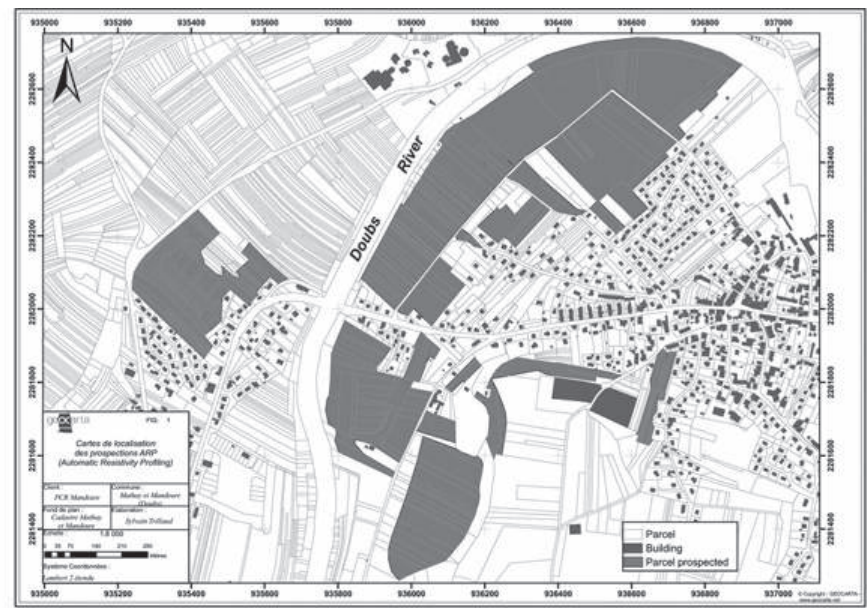

Archaeological surveying at Ancient Epomanduodurum Location of ARP system mapping (2004 - 2007)
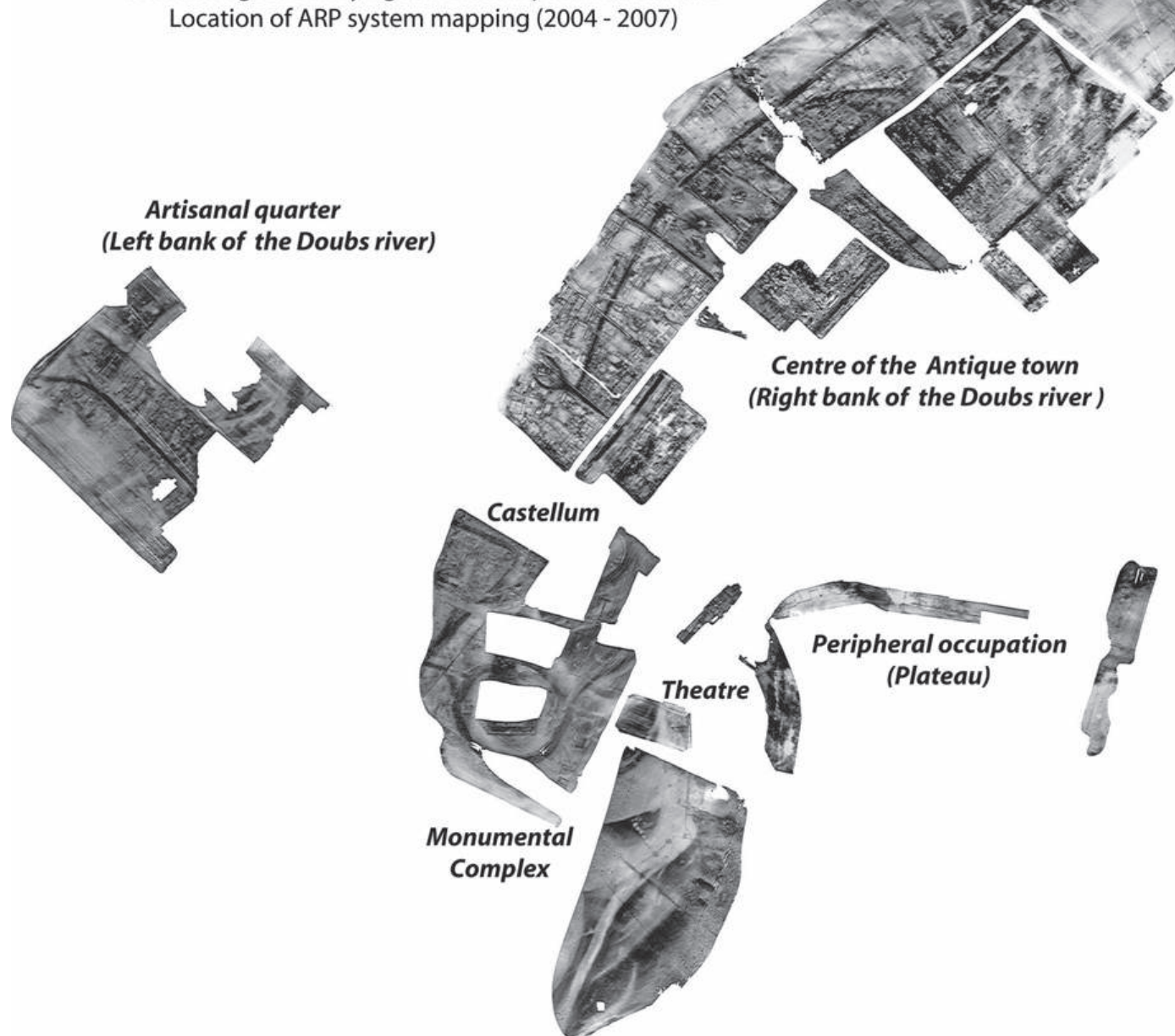

Figure 1: Mandeure-Mathay (Franche-Comté, Eastern France) Mapping of apparent electrical resistivity (1 m deep). ARP system (Automatic Resistivity Profiling) Adjusted resistivity scale (resistive value in dark, conductive value in clear) (Data Geocarta/PCR Mandeure. Data Processing - S. Trillaud, G. Bossuet, M. Thivet, 2008). 


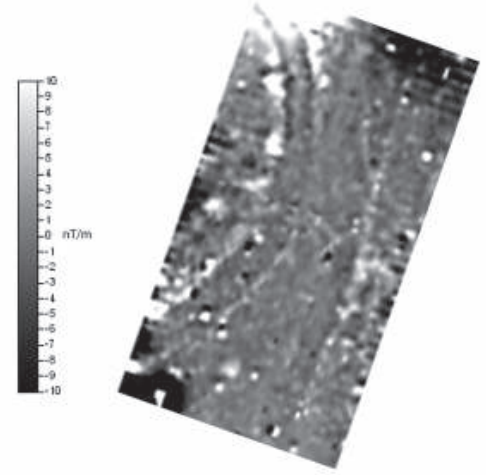

2a - Magnetic map detail from the 40 hectares survey showing the monumental structures detected at "Les Fougères". Fluxgate gradiometer Ferex CON 60-Foerster

[Geocarta/PCR Mandeure - E. Barrès, G. Bossuet, L.Aubry, 2003)

Figure 2: Mandeure «Les Fougères ».

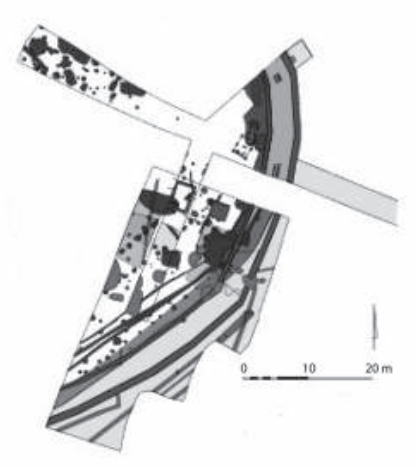

2b-Excavation plan showing surrounding walls of the Roman sanctuary and scattering of the Gallic pits (PCR Mandeure -M. Thivet, P Nouvel, 2008)

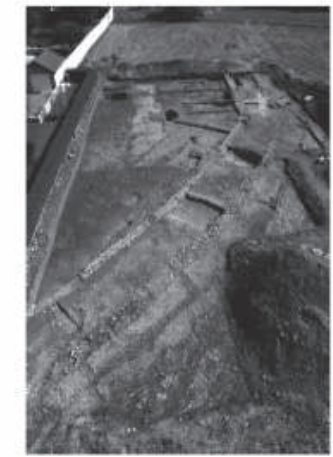

2c-Aerial view of the excavations showing rounded walls of different enclosures of the Roman sanctuary. (PCR Mandeure -photograhy M. Thivet, 2008)
- Studies of ancient maps, plans (18 $8^{\text {th }}$ and $\left.19^{\text {th }}\right)$ and archaeological inventories in order to spot the location of vestiges and the utilisation of former soils

- Airborne LIDAR (Light Detection And Ranging), aerial and satellite picture analysis

Selected anomalies will eventually be prospected by field walking and metal detector in order to determine their extent, their origin (natural or anthropogenic) and their chronology.

The geomorphologic context of the studied window is composed of the Doubs floodplain $(24.1 \%$ of the surface study) surrounded by two table-lands which are situated 100 meters above the plain. Today, the two table-lands are mainly forest-covered $(61.8 \%)$ but open field is also present on the plateau in a significant way (27.0\%). (fig. 3 )

While human occupation on open land is certified by a lot of indications, on the contrary, the forest-covered zones on table-land appear as less documented areas. The explanation is that some of the classic methods (such as aerial reconnaissance and field walking) are less efficient in the archaeological prospection of table-lands and hills, naturally marked by omnipresent forest. Thus we will use the LIDAR technology, particularly adapted for the detection and location of cultural resources (ancient fields, buried structures, graves) in forested environment. The LIDAR flight, on MathayMandeure window, is planned for the end of February or early in March, and the preliminary results for June.

\section{References}

Thivet, M., 2008. Méthodes Nouvelles de l'Archéologie appliquées au site antique de Mandeure/Mathay (Doubs). Reconnaissance spatiale, évolution chronologique, statut urbain. Thèse de Doctorat en Archéologie. Besançon Université de FrancheComté

Barral, P., Bossuet, G., Kuhnle, G., Marc, J.-Y., Mougin, P., Arcay, D., Bataille, G., Blin, S., Bride, A.-S., Burgevin, A., Camerlynck, C., Dabas, M., Dumont, A., Fort, B., Guillaumet, J.-P., Jaccottey, L., Jeunot, L., Joly, M., Marmet, E., Mazimann, J.-P., Mouton, S., Рichot, V., Schönfelder, M., Thivet, M. and Vannière, B., 2007. Epomanduodurum, une ville chez les Séquanes. Bilan de quatre années de recherche sur l'agglomération antique de Mandeure - Mathay (Doubs). Gallia, 64: 353-434.

Marc, J-Y.; Andre, N.; Barral, P., Blin, S.; Bossuet, G., Joly, M.; Mougin, P. and Thivet, M., 2007. "Le complexe du sanctuaire et du théâtre de Mandeure (Doubs, F), de ses origines gauloises à sa monumentalisation romaine ". In BeletGonda, C., Mazimann, J.-P., Richard, A., Schifferdecker, F., (dir.). Premières journées archéologiques frontalières de l'Arc jurassien. Mandeure, sa campagne et ses relations d'Avenches à Luxeuil et d'Augst à Besançon. Actualités archéologiques régionales. Delle (F) - Boncourt (CH), 21-22 octobre 2005, (2007), Presses universitaires de Franche-Comté et Office de la culture et Société jurassienne d'Émulation, 13-34 (Annales Littéraires; série Environnement, sociétés et archéologie 10 ; Cahier d'archéologie jurassienne 20). 
LIEPPEC (LIdar pour l'Etude des Paysages Passés Et Contemporains) PCR Mandeure, MSHE N.Ledoux

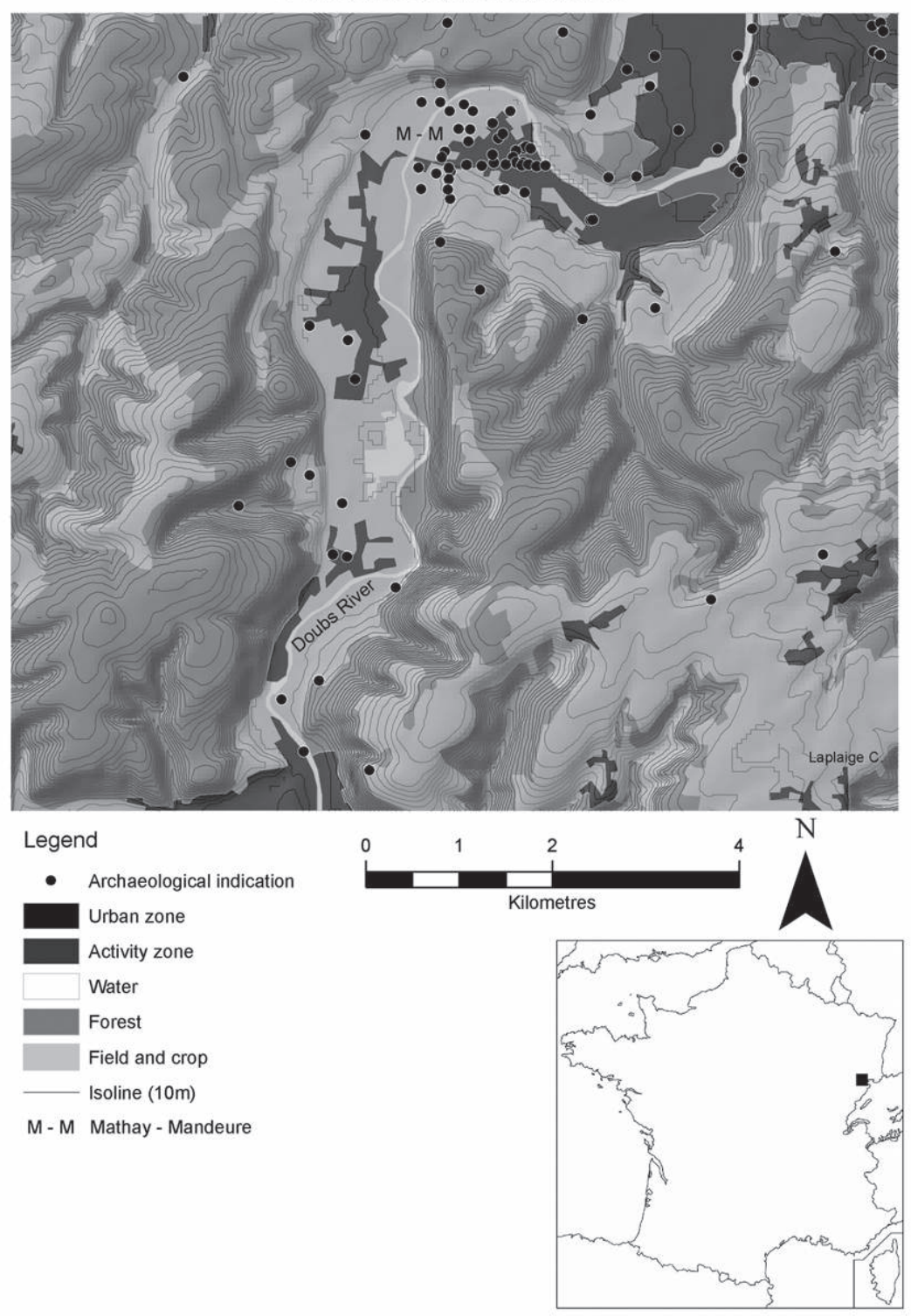

Fig. 3 - Location, soil occupation, archaeologicals indications and relief for the LIDAR window $\left(81 \mathrm{~km}^{2}\right)$ Thivet M., Bossuet G., Laplaige C.

Figure 3: Location, soil occupation, archaeological indications and relief for the LIDAR window $\left(81 \mathrm{~km}^{2}\right)$. 